\title{
The construction of a 'traditional' occupation: welding, 1900-1960
}

\author{
Alistair Mutch \\ The Nottingham Trent University
}

In a recent work on the nature of work and its impact on self-identity in the 'post-industrial' age, Catherine Casey makes the claim that 'By the 1980 s a number of occupations and former job categories such as welder, riveter, switchboard operator, salaries clerk, bookkeeper, typesetter (among many others) had disappeared'. 'The accuracy of such claims, in the case of welding at least, can be strongly contested, ${ }^{2}$ but they raise further issues about the use of notions such as that of the 'traditional occupation' in contemporary writing on occupation and class. These are used to develop an exaggerated contrast between the perceived constant flux and change of contemporary life as against the stability and order of the past. ${ }^{3}$ In Casey's defence it could be argued that, for welding at least, there is very little in the historical record to draw upon. As Penn argues, 'groups like welders ... have received virtually no systematic occupational analysis' despite being amongst the fastest growing occupations after the Second World War. ${ }^{4}$ This neglect of welding as an occupation relates not only to its current situation but also to its history. Indeed, it is difficult to locate an easily accessible account of the development of the technology, let alone the occupation. The outline which follows, therefore, is in part an attempt to remedy a gap in the literature.

Of course one has to recognise the dangers in approaching the past from the concerns of the present, although it could be argued that there are good examples of the value which sociologists can bring to a study of the past. ${ }^{5}$ However, if we are to correct the ahistorical bias alluded to above, then some risk taking seems in order. Labour history has paid relatively little attention to the detailed analysis of work and the labour process. ${ }^{6}$ Such accounts as do exist tend to deal with the nineteenth century and not with the emergence of the new science-based occupations of the twentieth century. ${ }^{7}$ These occupations involved a much wider network of actors, notably professional engineers and sub-contractors. Glucksmann's work on women assembly workers notes the importance of professional engineers in configuring particular arrangements of work in the 'new' industries of mass-produced consumer goods. ${ }^{8}$ In these industries new forms of the technical division of labour were shaped by existing ideas of sex-typed occupations. This shaping of new occupations by exist- 
ing assumptions also formed part of the development of welding as an occupation, but in this case it spanned the boundaries of a number of industries. There is a tendency to associate it with the older capital goods industries, such as shipbuilding and locomotive construction, but the crucial sites of development were in the ship repair and power generation industries. The latter was central to the spread of the use of electricity, a technology which in its turn helped the development of welding and the new assembly plants. In this way, welding as an occupation crossed the boundaries of industrial sectors in a manner which challenged the existing patterns of workplace organisation. In particular it brought engineers and boilermakers into conflict but in a context in which the occupation had largely been shaped at local level, raising interesting questions about the reaction of trade unions to occupational change. However, before considering the evolution of welding as an occupation it is necessary to review the development of the technology.

\section{JOINING METALS}

One major brake on the development of nineteenth century metal technologies was the restricted nature of the means of joining metal parts. These were really three: forging; mechanical fixing, including riveting; and soldering. The restrictions of all these methods - for example, the limited range of materials which could be joined, the addition of extra weight or the problems of ensuring supplies - meant that early in the century efforts were being made to find alternatives. Burton outlines attempts at 'welded' hulls in a shipyard in Woolwich in 1855 and at Derby railway works in 1868 the boilershop foreman experimented with 'welded' boilers. ${ }^{9}$ However, such ventures met with limited success and the emergence of welding as a practical technology depended on the maturing and application of the science of metallurgy and of two science-based technologies, electricity and the industrial use of gases.

At this point it is important to make a distinction between resistance and fusion welding. The former, involving the fusing of metals by the local application of electrical current, was developed in the early years of the twentieth century and was rapidly taken up in assembly work, at first for household articles but most notably in the developing automobile industry. It was distinct from fusion welding not only in its rapid adoption in manufacturing but also, and most importantly in this context, in its semiautomatic character. From its beginnings it was a technique which lent itself to automation and it was never classified as more than a semi-skilled job. This ease of automation was later to lead to the widespread use of robots in places such as car body assembly plants. Such developments, well publicised in many areas, may be behind claims such as those made 
by Casey. Whatever the truth of this, it was fusion welding that was the basis of the construction of the skilled craft of welding and that will be the concern of what follows. In fusion welding, two metal parts are heated and fused, in many cases with the addition of filler metal. Different techniques are needed to weld different thicknesses and types of metal, but they can be classified into two: gas and electric arc. Both of these were invented in the closing years of the nineteenth century but they had very different trajectories of adoption and diffusion. Gas welding stemmed from the discovery of techniques for making oxygen and then acetylene. The combination of these two enabled the development of cutting and welding technology, spurred on by increasing success in bottling gases. The portability of the equipment meant that it was widely adopted in the years immediately preceding the First World War as a repair technique. ${ }^{10}$ This widespread adoption hindered the take up of the much more flexible electric arc techniques.

These techniques, using electric current to create an arc generating intense heat, were also developed in the $1890 \mathrm{~s}$, but were hampered in part by the low penetration of electricity into many workplaces. ${ }^{11}$ This necessitated the installation of cumbersome batteries and power systems. ${ }^{12}$ Even when electricity became available from power generating companies, advances were still needed in generator design and, as Devine demonstrates, many factories were slow to adapt production techniques to the new potential. However, the use of the techniques to repair captured German ships in America at the end of the War and the construction of an all-welded barge by the Admiralty gave an impetus to its wider use. ${ }^{13}$ The first all-welded ship, constructed by the 'Quasi-Arc' system, was the 'Fullager' launched on the Mersey in $1920 .{ }^{14}$ In the same year the company involved with the Admiralty barge, Alloy Welding Processes Ltd, began the construction of a welded steel frame building in Brixton and the Welded Construction Company built an all-welded steel roof for a factory in the same location. ${ }^{15}$ These examples were precursors of the shift towards the use of welding as a manufacturing rather than a repair technology which was to take place during the 1930s. In part this was due to its acceptance by bodies such as Lloyds of London but it was also due to the rise of new industries such as aircraft building. By this time, developments in arc welding, such as the use of gases to shroud the arc and so create a higher quality weld, meant that it displaced acetylene welding. The Second World War marked a decisive shift with the massive expansion of the new industries and the overcoming of inertia in the old ones. The 1950s saw the consolidation of welding as a process and the rapid decline of a number of occupations associated with older means of metal joining. It is to the development of welding as an occupation that we now turn. 


\section{THE EMERGENCE OF AN OCGUPATION}

One problem for the study of welding as an occupation is that the evidence is mediated through a number of sources: union and trade journals; and Government publications. There is little real evidence on who became welders, their backgrounds and their training. Before 1921 any sort of numerical estimate is lacking. Welders were not included as a separate category in the major 1906 Census of Wages. ${ }^{16}$ However, these figures do include a comparison of wages in engineering between 1886 (the previous comprehensive census) and 1906 in which riveters demonstrate the largest percentage increase on time rates. ${ }^{17}$ Given that the majority of workers in engineering were on time rates (as opposed to shipbuilding, where most were on piece rates) this might suggest that employers in this sector had more interest in the development of a process which would replace riveters - especially as welding would replace a team with one, albeit skilled, person. Be that as it may, there is little discussion of the spread of welding in the reports of the Chief Inspector of Factories and Workshops, who usually included sections on industrial developments in the localities. It was not until 1910 that an inspector, significantly in Birmingham, 'draws attention to the increasing use of the oxy-acetylene flame for welding and cutting various metals' ${ }^{18}$ Subsequent references to acetylene welding are also in the Midlands.

These patterns of the early dominance of acetylene welding and of the importance of the Midlands find confirmation in the records of members admitted to the Boilermakers' Society. ${ }^{19}$ The Boilermakers were not the only union recruiting welders but they were the dominant one and so patterns in their recruitment and membership ought to be broadly indicative of trends in numbers and locations. Nevertheless, we must be sensitive to distortions caused by the depth and nature of organisation in particular areas. The Society was strongest in Scotland and the North East of England and so might not be in a position to recruit welders in other areas. However, the records indicate that in 192018 per cent of all welder recruits were in the West Midlands, suggesting that it was not in the shipyards that welding initially took hold. ${ }^{20}$ By the time it began to appear there, and by the time the Boilermakers and other unions began to take it seriously, the shape of welding as a skilled occupation had already begun to appear. However, this shape was not without debate, for not all agreed that welding ought to be a separate occupation, or that it was a skilled one. The major groups involved here were employers and professional engineers.

The widespread impact of welding sparked a considerable debate amongst employers and unions as to the nature of the new skill. An initial question was whether welding was indeed a separate occupation or 
whether it was an element in the repertoire of several trades. The latter view was most clearly stated in the decision of the American Federation of Labor that 'acetylene welding' is a process, and ... 'acetylene welder' is a tool, which can no more come under the jurisdiction of any one trade or calling than can the hammer or the saw'. ${ }^{21}$ This perspective fuelled the contention of some employers that welding was, at best, a semi-skilled trade which could easily be learnt in a short period. During an early debate one engineer argued that, 'He did not regard the training of welders as very essential, as electric welding was not a very difficult matter. He thought that an ordinary sensible worker with an aptitude for this work would very soon learn to do it, and as the work was not very hard he did not see any justification for the high prices charged for electric welding. ${ }^{, 22}$ Another speaker supported this with an explicit reference to wartime experience: 'With regard to the training of welders, the actual job did not take very long to learn. During the war girls had been trained to do this work in two days. ${ }^{23}$ However, another contributor to the debate reminds us of the need to be careful in our definitions. His argument was that 'it was not possible to train an efficient welder in two months' time to undertake every type of work that came along..$^{24}$ Clearly, it is important not to conflate the special conditions of wartime, in which considerable investment could be made in changes in production processes to cope with the limited skills available, with normal commercial conditions. ${ }^{25}$

This approach recognised that there were gradations in both the achievements of individual welders and of the demands of the jobs they would be expected to fulfil. Those who argued for welding as an easily acquired skill which could be used as a supplementary part of another occupation or could be engaged in by semi-skilled workers were no doubt correct if welding had been limited to repetitive, straight forward work, but this was by no means the usual case. The experience in the naval dockyards, for example, was that 'Only two men out of 150 had had to be rejected as unskillful, though only 30 per cent to 40 per cent of the total were really fit to employ on new construction. The remainder were kept on the minor and established work, which formed about 75 per cent, of the output at Plymouth'. ${ }^{26}$ This indicates both a hierarchy of skill and of demand, which were factors leading to the emergence of welding as a separate trade. Far from being a trade which could be acquired with ease, it was argued that 'it is necessary that a proper apprenticeship should be served under capable tuition'. ${ }^{27}$ In part this was due to lack of experience amongst professional engineers and hence a reliance on the skill of the welder. Cast iron, for example, required particular care and attention and 'The actual operation itself depends on the ability and resourcefulness of the welder' ${ }^{28}$ However, even with the learning gained through experience, skilled welding also demanded knowledge which could not be acquired 
this way. It required knowledge about the properties of metals, for example, that were not incorporated into the standard training of the fitter or boilersmith. Indeed it was delays in implementing this sort of training which were felt to be hindering the progress of railway companies in the use of welding. ${ }^{29}$ Not only were professional engineers dependent on welders for the development of their knowledge, but it could also be argued that the emergence of welding engineers as a separate professional grouping - the Institute of Welding was formed in 1935 - was given additional impetus by the existence of a skilled operative trade.$^{30}$ Indeed, one historian of welding has argued, with reference to the AFL ruling, that it 'has probably done more damage to the welding industry than any other single event. It prevented the organization of a union of welders on a craft basis, thus making it extremely difficult to set standards and to control qualification of welders. ${ }^{31}$ In addition to this there was a respect for the institutions of apprenticeship and skilled labour amongst many engineers. Thus O.V. Bulleid argued in his presidential address to the Institute of Welding that,

In welding we have a craft which demands a high standard of integrity and therefore it behoves us to develop the training of men to give us the craftsmen we need for the development of welding that lies before us. Do not let us pretend welding can be done by other than craftsmen, but let us see we support the craftsmen using welding and they will give the loyal service needed. $^{32}$

Therefore, in considering the emergence of a bundle of tasks as a skilled trade, therefore, we need to pay due attention to occupational coalitions. ${ }^{33}$ There is a tendency in debates about skill to portray management as a homogeneous entity, with a clear and unified strategy. ${ }^{34}$ The role of professional engineers in using the cause of the skilled man as a bolster to their own case should indicate one of the fault lines in this monolithic view.

We should, of course, be careful not to exaggerate the depth of this division. One qualification is that employers, like Adamson and Saxon of Manchester, were involved in these debates as engineer/owners. However, whilst they brought concerns and experiences of employment to the debate, these were refracted through shared conceptions of skilled work from an engineering perspective. The second qualification is that these conceptions limited the amount of debate on the detailed nature of the labour process. The unifying theme is the value of the skilled (British) workman used as more of a rhetorical device. One is reminded of the extent to which systematic consideration of the labour process is not a feature of the work of more recent design engineers. ${ }^{35}$ The debates amongst professional engineers are notable for the absence (aside from the 
exceptional comments by the likes of Bulleid) of a concern about the internal nature of welding as an occupation. Nor is there any consideration of the more explicit control dimensions of the employment relationship. Thus in the pages of the Proceedings of the Institution of Mechanical Engineers in 1922, a paper on electric welding prompted the comment, 'It was the first time that the difficulties raised by Trade Unions in the introduction of a new method had been referred to specifically in a Paper before a Technical Institution.' ${ }^{36}$ This same debate also revealed the limitations of the professional engineers' conception of a skilled occupation. The decision of one professional to enter into an agreement with the Boilermakers was greeted with shock and amazement. ${ }^{37}$ However, whilst recognising that the support for the creation of a skilled occupation was a limited and circumscribed one, such support was an important crack in an unitary perspective.

Whilst the professional engineers took the lead in the debates which played a part in shaping the occupation of welding, many employers had other things on their minds. In many ways the debates over the nature of the labour process indicated that skill was not the main concern, but rather control, and that control could be extended to more than just the labour process. ${ }^{38}$ Employers were also concerned with controlling cost (which might, of course, have an inter-relationship with skill) and with controlling markets. Many companies struggled to survive the depression years with too little capital for the major re-shaping of the production process that welding called for - from re-shaping physical plant to reequipping power sources. ${ }^{39}$ Whilst a major impetus to these changes would be given by the Second World War, it was in other emerging industries that welding began to take hold. We can see the emergence of welding as a distinct occupation when it was given the official recognition of being counted as a distinct category in the 1931 census. This showed that over a quarter of all welders were concentrated in the West Midlands, continuing the trend observed above. Some of this increase can be attributed to the more widespread use of resistance welding techniques in the growing motor industry but it was also related to the growth of the power generation industry in centres such as Rugby and Stafford. This marked the move of welding from a repair to a manufacturing technique, with reports appearing of the shortage of skilled labour. ${ }^{40}$ The balance was also slowing shifting away from acetylene welders, with only nine being recorded (11 per cent) amongst the eighty-five welders recruited by the Boilermakers that year. Thirty one were explicitly categorised as electric welders but the majority were unclassified. These figures have to be seen in the context of a much reduced intake to the union as a whole, with the traditional heartlands of the Clyde and Tyne and Wear sustaining the union in difficult times. Nevertheless, welders were becoming more im- 
portant in more regions of the union's activities. There was a particularly noticeable increase in the number of welders in the North East, reflecting the importance of ship repair on Teesside. ${ }^{41}$

The 1930s, of course, sees the beginning of the introduction of welding in shipbuilding, although this was not really to take off until the Second World War. There has been debate about the nature and causes of this introduction, with McGoldrick arguing that welding was seen as an opportunity to bring in a new technology at a national level. This in turn is connected to debates about the use of technology to establish control over the labour process. However, Roberts argues that, on the Wear at least, other factors meant that policy statements did not reflect progress on the ground. ${ }^{42}$ There are a number of arguments put forward for this. One is that the owners were not convinced of the advances claimed for welding, particularly given the nature of the Wear's output of tramp ships. This lack of conviction was shared by shipowners and classification societies such as Lloyds of London. This may well be the case, but it raises questions in the light of the example of the Fullager, the first all-welded merchant ship whose success in operation was clearly signalled in the trade press. ${ }^{43}$ This conservatism was bolstered by two factors: the cost of implementation and welder training and certification. On the first count, the introduction of welding meant not only increased costs for equipment but also, if full advantage were to be gained, the complete restructuring of production facilities. At a time when the dominant concern in the industry was over-capacity, incurring such costs was not easy. ${ }^{44}$ In addition, owners had to worry about the training and certification of welders. Whilst they might be able to tap into a source of welders amongst their sub-contractors, they also could face the problem of a two way flow of trained labour. Indeed, this had happened during the Fullager experiment. ${ }^{45} \mathrm{On}$ top of this there could also be problems with the inspection of the quality of completed work. Whilst imperfections in the individual rivets in a join might be countered by the rest of the work, this did not hold for welding. ${ }^{46}$ In addition, a simple visual inspection would not suffice. What was needed was the development of codes for the training and certification of welders, a process which took some time to gather momentum. When one adds to all these factors the need to face the existing practices of organised labour within the yards, one can see that many owners had powerful reasons for not pressing ahead with the introduction of welding. Further development really had to await the war years and after. This reinforces the point made earlier about the need to operate with a view of control which goes beyond the direct labour process to consider the broader context. ${ }^{47}$

Another industry where one might imagine welding would have been adopted was railway locomotive building. Here again one has to look at 
established practices and existing facilities as barriers to changes in technology. Whilst welding was used as a repair technique as early as 1914 at Crewe and 1918 at Eastleigh, it had to wait until the 1940s and the pioneering work of Bulleid in the 1940s for significant use to be made of it in fabrication. ${ }^{48}$ Certainly, welding occupies a marginal place in the memoirs of those who worked in the large company workshops in the 1940s. At Crewe this was reflected in physical arrangements: 'The shop was split into two parts rather as though it was an afterthought with the arc and gas welding tucked away at the North East corner of the Smithy and the oxy-acetylene cutting in part of the Finished Parts Store. ${ }^{, 49}$ Here welding here was used exclusively as a means of repair, as it was at Swindon. ${ }^{50}$ In part, the railway companies faced the same problem as shipbuilders of training skilled workers, but they also had the problem of buildings and plant which were designed for production methods based around the central supply of power to machines. ${ }^{51}$

This reminds us of the symbiotic relationship between welding and electricity. Not only did electric welding need reliable and flexible sources of power but also its use benefited from the clearing away of the clutter of belts that typified the pre-electric factory. ${ }^{52}$ In turn, welding was of great importance in the construction of the new power stations, both in the building of the boilers and turbines and in the construction of steel framed buildings. ${ }^{53}$ Another significant new industry which made heavy. use of welding was the chemical industry, with its need for smooth, sealed containers. It is to these industries, together with the developing automotive and aviation industries that one must look for the major developments leading up to the Second World War. ${ }^{54}$ One feature of these industries was that in many cases their geographical location was away from the traditional centres of heavy engineering. For example, one of the pioneers of welding in the chemical industry was the Steel Barrel Company of Uxbridge. ${ }^{55}$ The question of geographical location was to have some significance for the pattern of union response.

Of course, the war was to prevent the taking of the Census in 1941, but the Boilermakers' figures indicate the increase in numbers entering the occupation of welding. In 194042 per cent of the 1494 welder recruits were classified as electric welders, with only seventeen, or just over 1 per cent, being recorded as acetylene welders. The branch data indicates that the areas of growth were in North West England and Scotland. The war years saw major efforts to stimulate the growth of welding, with significant Government training efforts. As a consequence the Institute of Welding collaborated with the Ministry of Labour to establish training centres capable of producing 5,000 welders a year. However, it is important to recognise the limitations of such training as it could not substitute for the experience needed to cover the full range of production. What was necess- 
ary was the re-organisation of production facilities to cope with a lower level of skill, and to this end particular attention was paid to practices in America. ${ }^{56}$ There, especially in the shipyards producing 'Liberty' vessels, production was specifically laid out to facilitate the use of semi-skilled labour. However, the special conditions which had prompted the design of these yards, plus some spectacular and well-publicised failures, meant that British employers were a little sceptical about copying such methods directly. What they do indicate is the importance of recognising gradations in the skill employed in welding and the implications this might have for unions attempting to organise welders. By 1951 the Census indicates the spread of welding as a significant occupation in all parts of the country. The technical journals start to record serious attempts to reorganise shipyards to take advantage of the new techniques and there is recognition of its use in general engineering in, for example, the replacement of castings by fabrications in the construction of machine tools. ${ }^{57}$ Again, the debates here indicate the importance of the inter-relationship between the issue of cost and skill. Whilst it was now accepted, for example, that welding was a skilled occupation, the replacement of teams of riveters by single welders had considerable cost advantages. In one Sunderland yard, thirty-one welders replaced twenty-two riveting squads. These squads were comprised not only of the riveter and holder on but also heaters and catchers. The new arrangements meant an increase in the number of platers. This increased the skill composition of the remaining workforce but also gave rise to a net saving of thirty-one men. ${ }^{58}$ These changes, of course, had considerable implications for the unions involved and it was after this date that disagreements between unions started to surface at the national level.

\section{UNIONS AND WELDING}

It was quite clear by 1930 that there was a skilled occupation of welder which needed a substantial training period, a training period which in many cases had been assimilated to the traditional apprenticeship pattern. Such a trend was reinforced by the demands of trade unions, notably the Boilermakers and the Engineers. Their chief concern was not, however, with training but rather with job maintenance. Their initial attempt was to replicate the employment patterns to be found within riveting squads and to ensure access to training for their members. Thus, in the construction of the Fullager by Cammell-Laird on Merseyside, the welding work was given, under pressure from the Boilermakers' Society, to riveters, platers and caulkers rather than to specially trained welders. ${ }^{59}$ This reflects the fact that welding as an occupation was not constructed in a vacuum but was shaped by the patterns of existing union organisation. In the USA the union which was rebuffed in its attempts to organise welders 
exclusively was the Blacksmiths: in the UK, the union most closely associated with welding has been the Boilermakers. However, establishing the pattern of the organisation of welders has its own problems. There appears to have been little discussion on a broader level of the implications of welding. Indeed, the Trades Union Congress (TUC) preferred to leave this to individual unions. Even in awards of the disputes committee it shied away from setting binding decisions. ${ }^{60}$ One exception was the attempt by the Confederation of Shipbuilding and Engineering Unions in 1945 to put in a claim to the Engineering Employer's Federation for a skilled rate for welders plus a system of apprenticeship. This was refused on the grounds that 'welding was an operation which had such a wide range of uses and which called for such varying degrees of skill that it would be impossible to grade all welders into one skilled class' ${ }^{61}$ This common view meant that as welding was present in a variety of industries, so welders were organised by a number of unions. Coming to an overall picture of the level of organisation is, therefore, difficult.

Yet even at the level of individual unions, it is often hard to discern debate on whether welders constituted a single group of skilled workers. In the Boilermakers' Society, for example, there was no annual conference until 1952 at which such issues could be debated. Their monthly report was used effectively as a form of communication on matters of administrative detail and was dominated by lists of members admitted and 'run out'. There were some references to the potential impact of welding, but these were to be found in letters from the likes of Harry Pollitt which failed to spark off any deeper debate. ${ }^{62}$ Indeed, the history of the Society only contains its first reference to welding in the context of a letter from the Executive Committee (EC) to all branches in 1933 which talks of 'a new development which ultimately was profoundly to affect the membership of the Society. It was the development of the burning and welding of metal plates' ${ }^{63}$ It is ironic to note in this context an EC minute of 1909 in which the secretary of the Aberdeen branch 'asks advice re who should use Welding Lamp'. The response to this was that they should approach the District Delegate and 'keep him well informed' ${ }^{64}$ This seems to suggest that the process of informing stayed at the local level for the EC minutes reveal no debate on the issue. ${ }^{65}$ Moreover the first debate at the Society's inaugural Annual Conference was on demarcation when calls for a national policy were vigorously opposed by the EC: 'The question can only be settled in the district according to the local customs which apply in the district. ${ }^{66}$

Similarly, the disputes on this issue which were referred to the TUC represent only the tip of the iceberg, reflecting the TUC's anxiety for issues to be remedied at local level. The record of disputes involving welding should not be regarded as comprehensive but as an indication of 
the range of unions that were involved. The following cases concerning welders were reported by the TUC's Disputes Committee:67

1946 Birmingham and Midland Sheet Metal Workers' Society and Amalgamated Engineering Union

1949 Shipwrights and Boilermakers

1953 Engineers and Boilermakers

1955 National Union of Vehicle Builders and National Union of Sheet Metal Workers and Braziers

1962 Engineers and Boilermakers

1963 National Union of General and Municipal Workers and Associated Blacksmiths' Forge and Smith Workers Society

1965 Engineers and Boilermakers

The continuing conflict between the Engineers and the Boilermakers illustrates two contradictory pressures. The Engineers were trying to maintain negotiating rights over an entire workforce while the Boilermakers wanted to retain control over a particular craft. In part this reflected the desire to maintain union identity, but it also represented the desire of individual workers to have their skill recognised both by higher rewards within the plant and by the ability to move to other workplaces. Thus the Blacksmiths argued (unsuccessfully) that the welders they had recruited 'wished to change their union to one catering for their grade, which would widen their opportunities of other employment outside Tubewrights' ${ }^{68}$ The craft unions, like the Blacksmiths and the Boilermakers, were prepared to relax their insistence on apprenticeships in an attempt to recruit those who had been trained within a company. ${ }^{69}$ Throughout this period, the TUG tended to favour the status quo and so the mixed pattern of representation continued. In many cases this came down to local conditions. In a dispute between the Sheet Metal Workers and the National Union of Vehicle Builders, for example, it was reported that 'in Edinburgh we had done all the metal work including welding ... the amount of work we were able to secure depended entirely on our own strength in the shops ${ }^{70}$ The local nature of such disputes make them difficult to uncover but the variety of inter-union conflict that welding engendered is at least illustrated by those disputes recorded.

This pattern reflected the wide variety of impacts that welding had. Far from being a straight-forward process of the replacement of one craft, riveting, by another, welding, it had considerable repercussions on other trades. In the shipyards the trade which suffered most was caulking which was replaced entirely. The change in production methods towards more prefabrication also brought the Boilermakers into conflict with the Shipwrights. ${ }^{71}$ In general engineering the changes were in some ways more indirect, although the impact on the Blacksmiths was immediate. 
Employment for molders also reduced as many more parts which had been previously cast could now be fabricated from sheet metal. The production process in many plants involved the cleaning of the imperfections of these castings by legions of apprentices and their further machining and assembly. This process was replaced by the more accurate fabrication of items and the welding together of sub-assemblies. These changes directly affected the work of the fitter. The multiple impacts were well summarised in relation to shipbuilding by Finlay Hart in 1945:

All trades are affected by the extension of the welding process. Some gain, others lose. For example, blacksmiths who did all their welding on the fire, are now finding much of their work being done by electric welding. That means a loss of work to them. On the other hand the ship plumbers who substituted welded flanges on pipes for riveted flanges before the last war are now making up all kinds of fittings such as chests and valves etc., which were previously made of cast iron, thereby taking work away from the moulders. That in turn affects patternmakers, so we can see how large scale introduction of welding brings about many changes in the industry. ${ }^{72}$

The lack of attention to the development of welding by trade union historians means that we lack detail on how the process unfolded. In addition, our search is constrained both by the survival of records and the poverty of official sources. The data that can be gleaned from the records of the AEU, for example, is restricted. The union has very sketchy membership data compared to the Boilermakers. The mass of detailed statistics in its monthly and annual reports are organised primarily around class of membership rather than occupational categories. However from 1922 until 1939 the Annual Report contains a table indicating recruits by trade. $^{73}$ Welders first appear as a separate category in this table in 1936 when they represented 1.28 per cent of new members. By 1939 the AEU had recruited at least 3,894 welders, which compares favourably to an estimated 4,000 to 5,000 for the Boilermakers. There are indications, however, that the engineers began to recruit welders at a very much earlier date, and as a result came into conflict with the Boilermakers. Thus in the report of the Liverpool division for January 1921 we find the comment that:

We have been experiencing some trouble with boilermakers using the welding plant on engineers and smiths' work. As a result of our energetic protest, a fitter has now been placed on the plant. It behoves our members everywhere to be alert and capture the working of this plant. ${ }^{74}$

Similarly, the Bolton District Committee (DC) had to consider in 1924 the case of 'our members taking on Electrical Welding which had been the monopoly of the Boiler Makers at this firm'. The DC decided to support this move and to wait for complaints from the Boilermakers. ${ }^{75}$ These disputes remained at largely local level. One reason may be the tradition 
of local autonomy over such issues, with little monitoring at a national level. A second cause was the geographical dispersion of welding which meant that, in most cases, conflicts were avoided until welding matured as an occupation. Thus, in the first half of 1936 the AEU recruited 133 welders, nearly 80 per cent of whom were in London and the Home Counties, with three quarters of these being in areas where the Boilermakers did not have a branch. ${ }^{76}$ This geographical separation began to be challenged in the 1950s, particularly as Boilermaker members started to leave the shipyards and move into other areas, notably construction. The relative flexibility of welding made them a particularly mobile workforce, and different traditions of organising began to clash. ${ }^{77}$

We can see the dynamics of the process in the local records which survive. One point brought out by the minutes of the South Wales DC of the Boilermakers' Society is the importance of the ship repair business and sub-contracting firms in proving the effectiveness of welding. The efforts of the DG went towards the protection of the agreements under which welding was to be allowed. These stipulated that 'The Lamp to be used on ship and boiler repairs by three Journeymen' and that 'In all other cases of jobs on which the Lamp is to be operated, the number of men to be engaged shall not be reduced below the number that would be required were the Lamp not used' ${ }^{78}$ These attempts to maintain employment of Society members were under constant threat from a number of directions. One was from their own members working for the specialised welding firms. In August 1920, for example, there was a report of members working for the British Arc Company not 'working according to regulation of the three men being attendant upon the Arc whilst welding,79 Such problems were reported eight times that year, and formed the main cause for concern. Such worries were exacerbated by the failure of other unions to enforce the regulations. The Swansea branch reported that a welding firm 'were asking permission to be allowed to employ 2 men only on Plant, mention also being made that A.E.U. practice is that 2 men only are employed' ${ }^{80}$ Concern was also expressed at the use of welding by subcontractors who evaded the tight controls exercised within the yards themselves. In June 1920 the Committee investigated the allegation that a member had welded short-handed. The member in question worked for a sub-contracting firm owned by a Society member. The foreman at the main firm, also a Society member, had put the work out assuming that because the firm was organised there would be no problem. The welder admitted to working with only a labourer for an assistant and the Committee fined all three men two pounds each. ${ }^{81}$ This sort of draconian discipline could work successfully in the brief boom period after the First World War but the coming of mass unemployment made it much harder to enforce. ${ }^{82}$ 
What such incidents indicate is widespread experience at local level in dealing with the problems that welding brought in its wake. It suggests that employers were happy to let specialist firms and sub-contractors bear the burden of sorting out the technical and organisational issues. A suggestive pointer here is the comment by R.S. Kennedy of the British Arc Welding Company that,

so far back as March 1910, it was arranged by the writer with the Boilermakers' Society that electrical arc welding on hull and boilers was to be their job. On the whole it had not worked badly, and they had avoided the troubles of the oxy-acetylene welders of that time largely due to a frequent use of the handy man. ${ }^{83}$

Thus it seems that, at some level, the Boilermakers were aware of, and negotiating about, the contours of welding at a much earlier date than is apparent from the 'public' record. Why was the local experience not generalised within the Boilermakers' and the Engineers' Societies and from there into the wider labour movement? It certainly suggests a conservatism and a lack of strategic thinking in relation to the introduction of new technology.

\section{CONCLUSION}

This brief review of the history of welding as an occupation shows how shaky notions of 'traditional' occupations are. Contemporary sociology is often guilty of conflating occupational trajectories and of assuming that their status was assigned on creation. As we have seen, welding was shaped by a number of factors. One of these was the influence of professional engineers in moulding the new occupation through a discourse of skill. The development of this discourse in relation to manual occupations as well as in furthering the aspirations of professions might bear further investigation. Sub-contractors played an important role in the practical application of the technology and thus in the constructing of the occupation, but the unions paid little attention to lessons which might be learned from this experience. There is a contradictory message here: welding as an occupation is much older than current historical treatments allow, but the earlier phase of its adoption does not seem to have played a central role in shaping responses to it. There is the paradox, at least for the Boilermakers, of a very early engagement with a new trade, yet, apparently, little was learnt from this experience. This raises two linked questions: that of the effectiveness of union structures in conveying information about new developments and that of the strategic response, or lack of it, to new technology. This in turn has to be overlaid by the powerful symbolic weight, both in the historical account and within labour movement organisations, of certain occupations or industries. In our case this is shipbuild- 
ing. In the historical record this emphasis gives a distorted view of the development of welding. Of course, such symbolic importance is partly inspired by certain romantic images but they also have a material base: class formation is not simply a matter of numbers but has a crucial qualitative dimension. Certain groups of workers, for various reasons, can play a part far beyond their numerical strength. However, the danger is that such symbolism can prevent reasoned responses to changing conditions. Within unions like the Boilermakers, shipbuilding provided a significant part of the membership and had played a crucial role in the creation of the union. However, it is important to remember that the union also organised workers in railway workshops, ship repair, steel fabrication and general engineering - although this might not be the impression one would have from reading the union's Monthly Report. Indeed one indicative symbol is the front cover of this report. From 1913 the front cover changed from a stylised representation of the various industries covered by the union to one which incorporated a photograph, almost always of a shipbuilding subject. ${ }^{84}$ It could be suggested that such symbolic weight tended to divert attention from developments elsewhere. Certainly, changes in other areas such as ship repair were to be of profound significance.

This point is worth further exploration, as is the role of unions in the shift to new skills and occupations. It would be useful to have a breakdown of union membership, both by industrial sector and by occupational group. Such an analysis would provide the context for a qualitative examination of the skills involved, an area which More reminds us is relatively little explored but which would have a profound contemporary resonance. ${ }^{85}$ Such a study might also reflect on the impact on unions of changing occupations. In his work on the EEPTU Lloyd suggests a form of 'occupational determinism', citing Citrine's argument:

I have said many times that it seemed to me to follow that a union whose members had essentially to equip themselves with a considerable depth of theoretical knowledge in order intelligently to understand their work, must apply that same sort of analytical sense to the problems of the working class. It seemed to me to be inevitable that the membership of this trade union would - without any sense of distinction or arrogance or anything of the kind - tend to be on a somewhat higher intellectual level than that of the rank and file of trade unions who were not concerned with these problems. ${ }^{86}$

Whilst the Electrician's union was indeed one of the first to appreciate the need to monitor and research trends in its environment, it was someway behind the steelworkers. ${ }^{87}$ The relationship between union membership and union policy is somewhat more complex than Lloyd allows, although it is one which could stand further investigation. 
This review of the construction of welding as an occupation reveals the limitations of notions of 'traditional' occupations. It also indicates that attention to both capital and labour is needed if we are to understand the dynamics of the interplay of technology and occupational structure. Whilst both labour process and institutional history are important, they need to be set in a wider context. Not only should contemporary sociological debates on the nature of occupational change have an adequate historical dimension but that historical dimension should explore the full range of actors involved and the networks that linked them.

\section{ACKNOWLEDGEMENTS}

My thanks are due to John Walton for comments on an earlier draft and to a referee for very stimulating and helpful criticisms. Thanks also to Melanie Tebbutt and staff at the Working Class Movement Library, Salford and the Modern Records Centre, University of Warwick. This article is dedicated to Les Tebbutt, engineer and welder.

\section{REFERENCES}

${ }^{1}$ C. Casey, Work, Self and Society. After Industrialism, London, 1995, p. 37.

${ }^{2} \mathrm{~A}$. Mutch, "The impact of information technology on "traditional" occupations: the case of welding', New Technology, Work and Employment, 13, 2, 1998, pp. 140-9.

${ }^{3}$ A. Callinicos and C. Harman, The Changing Working Class. Essays on Class Structure Today, London, 1987.

${ }^{4}$ R. Penn, Class, Power and Technology, Cambridge, 1990, p. 45.

${ }^{5}$ For example, I. Carter, Farm Life in Northeast Scotland 1840-1914, Edinburgh, 1979; I. Roberts, Craft, Class and Control: the Sociology of a Shipbuilding Community, Edinburgh, 1994.

${ }^{6}$ P. Joyce, 'Work', in F.M.L. Thompson (ed.), The Cambridge Social History of Britain 17501914, Vol. 2, Cambridge, 1990, pp. 131-94.

${ }^{7} \mathrm{C}$. Evans, A skilled workforce during the transition to industrial society: forgemen in the British iron trade, 1500-1850', Labour History Review, 63, 2, 1998, pp. 143-59; K. McClelland and A. Reid, 'Wood, iron and steel: tcchnology, labour and trade union organisation in the shipbuilding industry, 1840-1914', in R. Harrison and J. Zeitlin (eds), Divisions of Labour: Skilled Workers and Technological Change in Nineteenth Century England, Brighton, 1985, pp. 151-84

${ }^{8} \mathrm{M}$. Glucksmann, Women Assemble: Women Workers and The New Industries in Inter-war Britain, London, 1990.

${ }^{9}$ A. Burton, The Rise and Fall of British Shipbuilding, London, 1994, p. 110; J.B. Radford, Derby Works and Midland Locomotives, London, 1971, p. 48.

${ }^{10}$ A.C. Nunes, 'Gas welding origins', Welding Journal, June 1977, pp. 15-23.

${ }^{11}$ W.D. Devine, 'From shafts to wires: historical perspectives on electrification', The Journal of Economic History, XLIII, 2, 1983, pp. 347-72.

${ }^{12}$ A.N. Kornienko, 'One hundred years of arc welding', Metal Construction, March 1982, p. 146.

${ }^{13}$ R.D. Simonson, The History of Welding, Illinois, 1969; K. Winterton, A Brief History of Welding Technology, Canadian Department of Mines, Ottawa, 1961.

14‘The Fullager', Engineering, 13 February 1920, p. 216. 
15‘Arc welding developments', Engineering, 30 January 1920, p. 153; 'Electric welding in building construction', Engineering, 14 May 1920, p. 655.

${ }^{16}$ Report of an enquiry by the Board of Trade into Earnings and Hours of Labour of Workpeople of the United Kingdom, vol LXXXVIII, 1911, Engineering and Boilermaking.

${ }^{17}$ Ibid., p. xxxiv.

${ }^{18}$ Annual Report of the Chief Inspector of Factories and Workshops, 1910, Cd. 5693, xxii, p. 39.

${ }^{19}$ United Society of Boilermakers and Iron Shipbuilders Monthly Report, Working Class Movement Library (WCML), Salford. All subsequent figures are based on an analysis of the list of members contained in each report.

${ }^{20}$ Sixty-four per cent of welders recruited were acetylene welders, confirming the observations made by the Factory Inspectors.

${ }^{21} \mathrm{AFL}$ Executive Council cited in B. Mergen, 'Blacksmiths and welders: identity and phenomenal change', Industrial and Labor Relations Review, 25, 3, 1972, p. 357.

${ }^{22}$ 'The Institution of Mechanical Engineers, NorthWestern Section', Engineering, 3 March 1922, p. 258.

${ }^{23}$ Ibid.

${ }^{24}$ Ibid.

${ }^{25} \mathrm{C}$. More, Skill and the English Working Class, 1870-1914, London, 1980, pp. 28-36.

${ }^{26}$ 'Welding in ship construction', Engineering, 21 April 1933, p. 442.

${ }^{27}$ E.A. Whittaker, 'Practical applications of gas welding', Engineering, 2 November 1923, p. 572.

${ }^{28} \mathrm{Ibid}$

${ }^{29}$ 'The training of welders', Engineering, 14 March 1930, pp. 349-50.

${ }^{30}$ 'The Institute of Welding', Engineering, 14 June 1935, p. 631.

${ }^{31}$ Simonson, History of Welding, p. 102.

${ }^{32} \mathrm{Mr}$ Bulleid's Presidential Address', Institute of Welding Transactions, 12, 1949, p. 138.

${ }^{33}$ E.A. Krause, The Sociology of Occupations, Boston, 1971, pp. 88-90.

${ }^{34} \mathrm{~J}$. Kelly, Trade unions and socialist politics, London, 1988.

${ }^{35} \mathrm{~J}$. Benders, Optional Options: Work Design and Manufacturing Automation, Aldershot, 1993.

${ }^{36}$ This comment is one of a number appended to the main discussion in A.T. Wall,

'Electric welding applied to steel construction, with special reference to ships', Proceedings of the Institution of Mechanical Engineers, 1922, p. 272.

${ }^{37}$ Ibid., p. 287.

${ }^{38} \mathrm{M}$. Burawoy, The Politics of Production, London, 1985.

${ }^{39} \mathrm{~A}$. Ayre, 'Electric welding in United Kingdom shipyards during the past quarter of a century', Institute of Welding Transactions, 5, 1942, pp. 152-5.

${ }^{40}$ IME North Western branch', Engineering, 21 March 1930, p. 387.

${ }^{41}$ Seventeen per cent of all welders were recruited on Teesside; more detailed work at a local level would be needed to establish the exact nature of the workplaces involved, but they would appear to be outside of shipbuilding.

${ }^{42} \mathrm{~J}$. McGoldrick, 'Industrial relations and the division of labour in the shipbuilding industry since the war', British fournal of Industrial Relations, 20, 1982, pp. 197-219; I. Roberts, Craft, Class and Control: the Sociology of a Shipbuilding Community, Edinburgh, 1994.

${ }^{43}$ Engineering, 21 March 1930, p. 386.

${ }^{44}$ The continuing debate about mass production versus flexible specialisation is also of relevance: J. Zeitlin, 'Between selective flexibility and mass production: strategic ambiguity and selective adaptation in the British engineering industry, 1830-1914' in C. Sabel and J. Zeitlin (eds), Worlds of Possibilities: Flexibility and Mass Production in Western Industrialization, Cambridge, 1997, pp. 241-72 
${ }^{45}$ A.T. Wall, 'Electric welding applied to steel construction, with special reference to ships', Engineering, 24 February 1922, p. 242.

${ }^{46}$ See also More, Skill and the English Working Class.

${ }^{47}$ Glucksmann, Women Assemble.

${ }^{48} \mathrm{~F}$. Hazeldine, 'Oxy-Acetylene welding', Proceedings of the Institution of Mechanical Engineers, 1919, p. 130; F. Hargreaves, 'Welding in locomotive construction and repair', Institute of Welding Transactions, 12, 1949, pp. 98-104.

${ }^{49} \mathrm{C}$. Taylor, Life in a Loco Works. First-hand experiences of a Crewe engineering apprentice in wartime, Yeovil, 1995, p. 131.

${ }^{50}$ K. Gibbs, Swindon Works Apprentice in Steam, Yeovil, 1986.

${ }^{5}$ N.S.C. Macmillan, Locomotive Apprentice at the North British Locomotive Co., Brighton, 1992.

${ }^{52}$ Devine, 'Shafts to wires'.

${ }^{53}$ There are scattered clues to this in the AEU reports: the 1932 Appeals section of the Annual Report (MSS.259/4/15/32) refers to welded brackets in the Metro-Vickers plant in Openshaw, Manchester.

${ }^{54}$ See also 'Summer meeting of the Institute of Electrical Engineering in Scotland', Engineering, 26 June 1936, pp. 692-3 - Babcock and Wilcox of Renfrew; E.H. Lee, 'Fabrication and welding in the heavy electrical industry', British Welding Journal, 1, 1954, pp. 385-91.

${ }^{55}$ Thomas Heaton, 'Some modern methods of welding', Proceedings of the Institution of Mechanical Engineers, 1914, pp. 151-200; Thomas Heaton, 'Electric welding', Proceedings of the Institution of Mechanical Engineers, 1919, pp. 49-72.

${ }^{56} \mathrm{~A}$ point made in the context of the First World War by More, Skill and the English Working Class.

${ }^{57} \mathrm{~J} . \mathrm{R}$. Ferguson, 'Welding in engineering production', Institute of Welding Transactions, 11 , 1948, pp. 170-80; R.J.W. Rudkin, 'Trends in modern shipyard welding', British Welding Journal, 1, 1954, pp. 487-94.

${ }^{58}$ W.R. Mellanby, 'Shipyard management of welding', Institute of Welding Transactions, 11 , 1948, pp. 52-65.

${ }^{59}$ A.T. Wall, 'Electric welding applied to steel construction, with special reference to ships', Engineering, 24 February 1922, p. 242.

${ }^{60}$ For example, the decision about Metro Vickers in Stockton on Tees where, despite the AEU calling for a decision of principle, the award was careful to confine itself to the case (TUC Annual Report, 1955, p. 99).

${ }^{6 !}$ National Union of Sheet Metal Workers \& Braziers, Executive Committee minutes, WCML, 30 October 1945, p. 5; 6 December 1946, p. 3. This mirrors practice in the USA: see Boilermakers-Blacksmiths fournal, the monthly journal of the International Brotherhood of Boilermakers, Iron Ship Builders, Blacksmiths, Forgers and Helpers, Kansas City, WCML, May 1958, p. 9.

${ }^{62}$ 'Workers, own the machine', letters from Harry Pollitt, Boilermakers Society Monthly Report, April 1920, p. 30; May, 1920 p. 19.

${ }^{63}$ J.E. Mortimer, History of the Boilermakers' Society, Vol. 2, London, 1982, p. 229.

${ }_{64}$ Minutes of the Boilermakers' Society EC, WCML, 23 August 1909.

${ }^{65}$ A. Mutch, 'Unions and information, Britain 1900-1960: an essay in the history of information', International Review of Social History, 44, 3, 1999, pp. 395-418.

${ }^{66}$ Boilermakers Society, Report of the First Annual Delegate Conference, WCML, 1952, p. 27.

${ }^{67}$ No disputes involving welding were taken to the Committee before 1946 .

${ }^{68}$ TUC, Annual Report, 1963, p. 107.

${ }^{69}$ TUC, Annual Report, 1953, p. 103.

${ }^{70}$ National Union of Sheet Metal Workers \& Braziers, Executive Committee minutes, 
WCML, 15 December 1944, p. 4.

${ }^{11}$ TUC, Annual Report, 1958, pp. 96-102.

${ }^{72}$ Finlay Hart, Demarcation and the Shipbuilding Trades, Communist Party pamphlet, London, 1945, p. 7, cited in J. Foster, The Politics of the UCS Work In, London, 1986, p. 136.

${ }^{73}$ AEU Annual Reports, Modern Records Centre (MRC), University of Warwick, 1922-39.

${ }^{74}$ AEU Monthly journal and report, MRC MSS. 259/4/14/35, 1921, p. 56.

${ }^{75}$ Minutes of the Bolton District Committee, AEU, WCML, 19 June 1924.

${ }^{76} \mathrm{AEU}$ half-yearly returns, WCML, 1936.

${ }^{77}$ On these traditions, see McClelland and Reid, 'Wood, Iron and Steel'.

${ }^{78}$ Working Rules and Conditions, Bristol Channel Ship Repairing, 1928, WCML, Misc ship 331881238 F200 Box 2, pp. 15-16.

${ }^{79}$ Minutes of the South Wales District Committee (SWDC), WCML, 28 August 1920.

${ }^{80}$ SWDC, 12 March 1921.

${ }^{81}$ SWDC, 5 June 1920.

${ }^{82} \mathrm{As}$ of course did changes in authority relations and the role of the foreman, changes which were influenced by the technological developments that welding represents: K. Burgess, 'Authority relations and the division of labour in British industry, with special reference to Clydeside, c.1860-1930', Social History, 11, 2, 1986, pp. 211-33.

${ }^{83}$ Wall, 'Electric welding' (IME), p. 284.

${ }^{84}$ See the analysis in Mutch, 'Unions' and information'.

${ }^{85} \mathrm{C}$. More, 'Reskilling and labour markets in Britain c.1890-1940: questions and hypotheses', Historical Studies in Industrial Relations, 2, 1996, pp. 93-110.

${ }^{86} \mathrm{~J}$. Lloyd, Light and Liberty. The History of the EEPTU, London, 1990, p. 664.

${ }^{87}$ Mutch, 'Unions and information'. 
Copyright of Labour History Review is the property of Maney Publishing. The copyright in an individual article may be maintained by the author in certain cases. Content may not be copied or emailed to multiple sites or posted to a listserv without the copyright holder's express written permission. However, users may print, download, or email articles for individual use. 